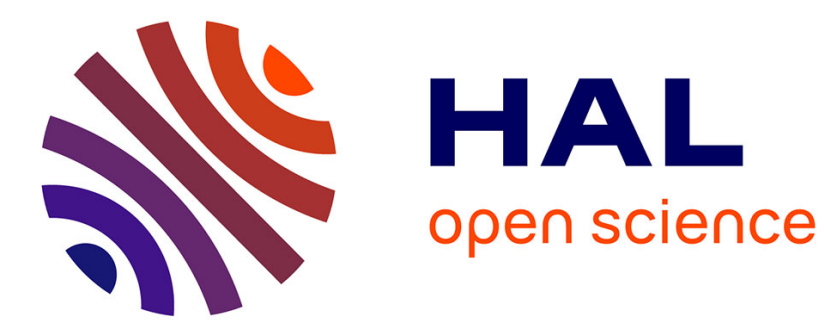

\title{
Testing for the stability of Money Demand in Italy: has the Euro influenced the Monetary transmission Mechanism?
}

Oreste Napolitano

\section{- To cite this version:}

Oreste Napolitano. Testing for the stability of Money Demand in Italy: has the Euro influenced the Monetary transmission Mechanism?. Applied Economics, 2011, pp.1. 10.1080/00036846.2011.570719 . hal-00711447

\section{HAL Id: hal-00711447 \\ https://hal.science/hal-00711447}

Submitted on 25 Jun 2012

HAL is a multi-disciplinary open access archive for the deposit and dissemination of scientific research documents, whether they are published or not. The documents may come from teaching and research institutions in France or abroad, or from public or private research centers.
L'archive ouverte pluridisciplinaire HAL, est destinée au dépôt et à la diffusion de documents scientifiques de niveau recherche, publiés ou non, émanant des établissements d'enseignement et de recherche français ou étrangers, des laboratoires publics ou privés. 


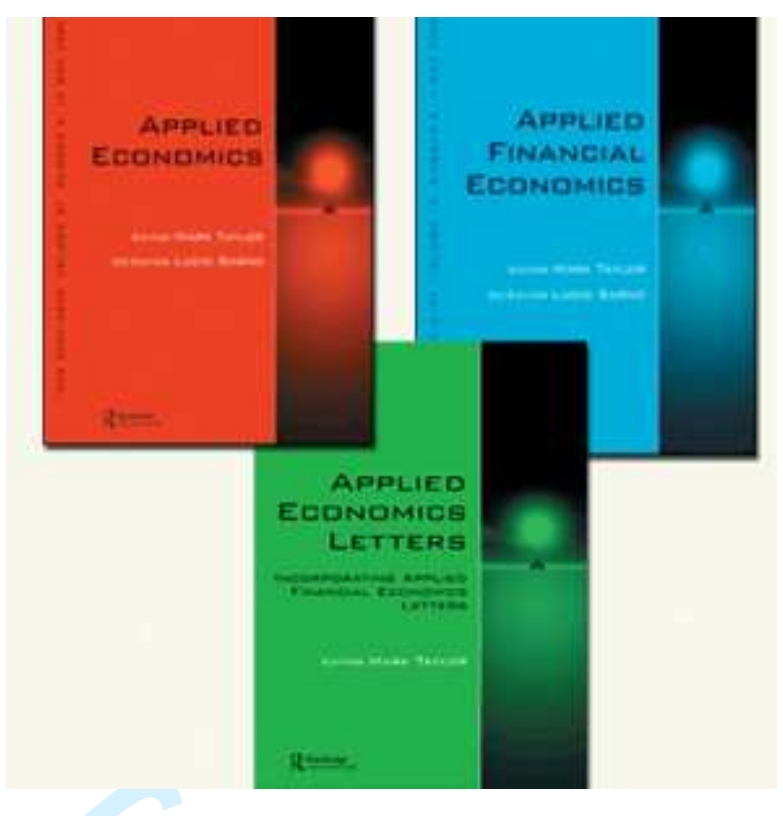

\section{Testing for the stability of Money Demand in Italy: has the Euro influenced the Monetary transmission Mechanism?}

\begin{tabular}{|c|c|}
\hline Journal: & Applied Economics \\
\hline Manuscript ID: & APE-2009-0402.R1 \\
\hline Journal Selection: & Applied Economics \\
\hline $\begin{array}{r}\text { Date Submitted by the } \\
\text { Author: }\end{array}$ & 25-Feb-2011 \\
\hline Complete List of Authors: & $\begin{array}{l}\text { Napolitano, Oreste; University of Naples Parthenope, Department of } \\
\text { Economics Studies- Salvatore Vinci }\end{array}$ \\
\hline JEL Code: & $\begin{array}{l}\text { E41 - Demand for Money < E4 - Money and Interest Rates < E - } \\
\text { Macroeconomics and Monetary Economics, C22 - Time-Series } \\
\text { Models < C2 - Econometric Methods: Single Equation Models < C - } \\
\text { Mathematical and Quantitative Methods, E58 - Central Banks and } \\
\text { Their Policies < E5 - Monetary Policy, Central Banking, and the } \\
\text { Supply of Money and Credit < E - Macroeconomics and Monetary } \\
\text { Economics }\end{array}$ \\
\hline Keywords: & Money demand, ARDL model, Kalman filter, Central Banks \\
\hline
\end{tabular}




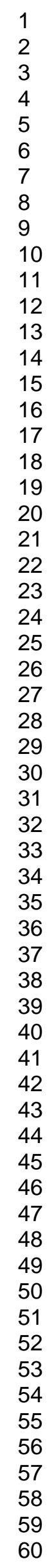

\section{SCHOLARONE ${ }^{m}$ \\ Manuscripts}

7

21

23

24

26

27

29

30

31

33

34

35

36

37

38

41

42

43

44

46

47

48

49

51

52

53

54

55

57

58

59

60 


\section{Testing for the stability of Money Demand in Italy: has the Euro influenced the Monetary transmission Mechanism?}

\section{Introduction}

Since the pioneering works by Keynes (1936) and Baumol (1952), money demand has been deeply and extensively studied by many economists. Yet to these days, many issues concerning the determinants and the dynamics of money demand remain obscure. In particular, given the importance for policy purposes of quantifying money demand and money supply, economists have focussed the attention on specific features of monetary aggregates which appear to differ across country and across time. One such feature is the stability of money demand. Indeed, because of the instability of the interest rates, exchange rates and, eventually, of inflation and output, money demand might be highly unstable. Moreover, the preference for liquidity in itself might be highly unstable because, for example, of wealth effects which influence non monotonically the demand for money. It follows that the degree of instability will strongly depend not only on the fluctuations of the individual components of money demand, but also on the degree of correlation of these components with one another. Hence, given that the short run and long run dynamics of these components can significantly differ from country to country and across time, so can the dynamics of money demand. This is particularly true whenever relevant shocks alter the composition and the structure of the financial market. To this respect, the formation of the EMU has undoubtedly caused a major shock to the monetary and financial market in the joining countries. The progressive increase in the degree of financial integration, in the liberalization of capital movements, and the augmented exchange rate stability in Europe, has caused domestic and foreign balances to become closer substitutes and has induced more people to hold more internationally diversified portfolios. If this is the case, one expect that in these European countries the stability of money demand might have been affected as well.

Despite the abundant literature on the issue developed over the last two decades (Juselius, 1998; Bjørnland, 2005; Bae et al. 2006, amongst others), few economists have investigated the stability of money demand in the major European countries following the EMU formation. These studies attempt to test for stability by employing simple cointegration analysis and to estimate mainly income and interest elasticities (Johansen, 1995; Muscatelli and Papi, 1990, Bahmani-Oskooe et al. 1998, Bahmani-Oskooee and Chomsisengphet, 2002, Brand and Cassola, 2004). Cointegration analysis, however, might not be sufficient to detect stability of money demand even when the estimated elasticities over time of the relevant variables appear to be stable. Hence, simple cointegration between the relevant component of money demand does not straightforwardly imply a stable money demand function. As a matter of fact, it has been shown that cointegration analysis should enclose short run as well as long run dynamics in order to be able to provide satisfactory test for stability of money demand. 
By taking into account the most recent econometric testing procedures, this paper intends to investigate the consistency of the stability of money demand in Italy, one of the larger EMU countries, before and after the EMU. In doing so we try to estimate the money demand function in Italy over a long period of time,1977-2007, using bounds testing cointegration procedure proposed by Pesaran et al. (2001). In order to compute the short and long-run elasticities of demand for money, we implement CUSUM and CUSUMSQ stability tests proposed by Brown et al (1975). We think that this procedure can shed new light on the consistency of money demand in Italy following major structural breaks in the monetary policy and in the Italian financial system in the last decades. Moreover, we perform our analysis not only on M2, which is the standard measurement of money demand, but also on broad money, M3, in order to better detect possible portfolio and wealth effects on money demand. Needles to say that this is a very relevant issue for policy since the stability of money demand is a crucial prerequisite for the efficiency of monetary policy interventions.

We choose to focus on Italy since Italy represents an interesting case among the other major European countries given that its monetary system has undergone several major changes besides the introduction of the single currency. Such changes have occurred through more than two decades, from 1977 to 1998, strongly affecting money demand and other monetary aggregates.

As a matter of fact, our investigation reveals that notwithstanding several institutional changes, over the long period money demand in this country can be considered to have been relatively stable and, interestingly enough, we find that the introduction of Euro has significantly increased the stability of money demand parameters. The relevance of this result is clear when one considers the implication for policy. The paper is organised as follows. Section 2 briefly frames the historical changes in the Italian monetary system. Section 3 describe the methodology we employ to test for the stability of money demand in Italy. The main results are outlined in section 4. Some final remarks are included in the concluding section 5.

\section{Historical background}

The seventies in Italy were characterized by high inflation and large budget deficits. During this period price control and currency stability were sacrificed to economic growth and employment. In terms of capital movements, Italy was isolated from foreign money markets due to extensive capital controls and foreign exchange transactions.

At the beginning of the eighties the Bank of Italy started to gain monetary policy independence from the fiscal authorities. A decisive event in this respect was the so called "divorce" from the Treasury in July 1981 which frees the Central Bank from the obligation to intervene and act as a residual buyer at the government securities auctions. The further significant event which marks a substantial change in monetary policy was the switch to M2 as an intermediate target. This took place between 1983 and 1984 and showed the intent of monetary authorities to target long-run objectives and to focus mainly on price stability.

Besides the internal challenges, Italian monetary policy had to face increasingly binding external constraints from its partnership to the Exchange Rate Mechanism (ERM). 
Before 1983 the ERM had been relatively flexible involving frequent realignments. After 1983 the regime became very stringent and involved quasi fixed exchanged rates to the extent that many economists consider the year 1983 as a break point between two different regimes. Hence, empirical studies on money demand either explicitly take into account this break in the data ${ }^{1}$, or, more simply, take the 1983 as the beginning of the sample ${ }^{2}$.

From the end of 1985 until the first months of 1988, Italy experienced perhaps the longest period of political stability.

During the second half of the eighties the quantitative constraints on capital movements were gradually relaxed loosening the monetary isolation from abroad. The numerous financial innovations occurring during these years contributed to engender other structural changes in the money market.

From the beginning of 1990 until the end of 1992 Italy experienced the effects of the decision taken by the monetary authority to join the narrow band in the ERM. The objective was to gain additional credibility from being a member of the "German club". The cost of this increase in credibility was the loss of competitiveness and a reduced possibility to finance the budget deficit. The Italian Lira was forced out of the ERM in September 1992, rejoining it in November 1996, this time with the new wider band of $\pm 15 \%$ introduced in August 1993 .

From 1992 on, the Treasury was no longer allowed to borrow from the Bank of Italy and only the Central Bank was allowed to fix the discount rate.

With the launch of the single currency in 1999, the primary goal of the European Central Bank (ECB hereafter) is to maintain price stability.

Considerable effort has been made by economists to estimate money demand function in Italy by taking into account such major institutional and economic changes. And the literature proposes different empirical approaches. Sarno (1999) and Muscatelli and Spinelli (1996) use historical annual data covering the period from 1861 to 1991 , and 1990, respectively. Working with single-equation estimation methods they study money demand function over the period and detect one cointegrating relationship. Along the same line of investigation, Angelini et al. (1994) estimate money demand function in Italy for the samples 1975-1979 and 1983-1991 by using monthly as well as quarterly data. They also examine the stability of their estimated money demand functions and find $\mathrm{M} 2$ to be stable.

By following different methodologies, Gennari (1999), Bagliano (1996), Rinaldi and Tedeschi (1996) and Juselius (1998) are not completely able to prove the stability of money demand in Italy and to provide an unequivocal sign for the coefficients on the different components (i.e. interest rate and income). Generally, these results are explained by the introduction of numerous financial innovations over the period and by the changes in the Italian exchange rate mechanism in 1983. Mainly, these economists perform cointegration analysis by implementing a multivariate framework and assume more than one cointegration relationship. They identify three (Bagliano, 1996, finds two) cointegrating vectors, one of them being the money demand relationship.

While these studies can test for non-stationarity of time series data by means of cointegration analysis, they are unable to rigorously test for the suitability of the estimated models in forecasting and policy analysis. Moreover, none of these studies, as

\footnotetext{
${ }^{1}$ Angelini et al. (1994) and Juselius (1998).

${ }^{2}$ Fanelli and Paruolo (1999) and Rinaldi and Tedeschi (1996).
} 
far as we know, is able to provide a strong evidence for the stability of money demand in Italy.

Among others, our objective is, indeed, to fill this gap and to provide a valid empirical model which can both account for the stability of money demand in Italy and it can be a viable tool for policy execution.

\section{The Methodology}

The main issue concerning the estimation of money demand is, of course, the characterization of money demand itself. In defining the demand for money, applied economists have usually focused only on those variables which the theory has proved to directly influence the demand for liquidity, i.e. short and long run interest rates, price level and income. The idea is that the demand for real money balances is ultimately influenced by transaction and speculative motives. Hence, following the prevalent literature, we model the demand for real money balances as a function of GDP, which measures the level of economic activity and underlines the transaction purpose for holding money, and as a function of short-term interest rate and inflation, which influence the opportunity cost for holding money and emphasize the speculative motive. Yet interest rate and inflation alone cannot exhaustively detect the speculative motives for holding money. In fact, in portfolio diversification, all assets, and of course their valuation, play a key role. Recently, the set of money demand explanatory variables has been extended to include others which can be thought of being not less relevant in causing the demand for liquidity: one such variable is the exchange rate (BahmaniOskooee and Pourheydarian, 1990; McNown and Wallace, 1992; Bahmani-Oskooe and Shabsigh,1996). The idea is that expectation of depreciation or revaluation can significantly affect money demand through changes in perceived wealth. For instance, the expected depreciation of domestic currency causes an increase in the value of foreign financial assets held by domestic residents in terms of domestic currency. If this increase is perceived as an increase in wealth, the demand for domestic currency could increase as well. Following this strand of literature, we include the nominal effective exchange rate among the explanatory variables for money demand.

Specifically, we choose to regress real money balances, $\tilde{M}_{t}=(M / P)_{t}$, alternatively measured by M2 and M3, on current and lagged values of GDP, $Y_{t}$, nominal interest rate, $R_{t}$, inflation rate, $\pi_{t}$, and nominal exchange rate, $E x_{t}$ :

$$
\begin{aligned}
\ln \tilde{M}_{t}=\alpha_{0}+ & \sum_{i=1}^{n} \alpha_{1 i} \ln Y_{t-i}+\sum_{i=1}^{n} \alpha_{2 i} \ln R_{t-i}+ \\
& +\sum_{i=1}^{n} \alpha_{3 i} \ln E x_{t-i}+\sum_{i=1}^{n} \alpha_{4 i} \pi_{t-i}+\mu_{t}
\end{aligned}
$$

where the coefficients $\alpha_{1 i}, \alpha_{2 i}, \alpha_{3 i}$ denote the elasticities of money demand with respect to income, interest rate, and nominal effective exchange rate, respectively, and $\alpha_{4 i}$ represents the semi-elasticity of money demand with respect to inflation. Yet prior to 
running estimations we check for consistency in the data, controlling for possible structural breaks. We then specify the error correction model.

\section{Empirical results}

\subsection{Long and short term Money Demand determinants}

Preliminary graphical analysis of monetary aggregates in figures 1 shows the presence of some jumps in the dependent variables, M2 and M3. Hence, it may be of interest to test for the stability of the coefficients. In order to do so, we run basic regressions of eq. (1) including up to three lags, with M2 and M3 in sequence as dependent variables. We then use the recursive residual test to identify a likely break in the series and the corresponding number of dummies. The results are shown in figures 2 and 3 in the appendix, where recursive residuals are plotted jointly with the zero line \pm two standard errors. The test identifies six impulse dummies ${ }^{3}$. The Chow test for structural breakpoints in the sample of eq. (1) confirms that these breaks are significant and decisively rejects the null hypothesis of no structural change for both the M2 and M3 series (the results are in table 1).

\section{[Figures 1, 2 and 3 about here]}

[Table 1 about here]

Once detected the presence of breakpoints in the data and constructed the dummies in order to correct for the parameters' instability, we turn to investigate the nature of the long-run and short-run relationships between money demand and its determinants in Italy over the period.

Over the past decade, many relevant studies have clearly proved that standard cointegration analysis by its own cannot fully detect the significance and the nature of stable linkages between variables. To this extent, cointegration analysis needs to be jointly employed with other tests which are potentially able to also uncover other features of variables' dynamics. Stability tests and error correction models, in this sense, are useful instruments to prove for the robustness of long run linkages between economic variables by taking into account the relevance of short run disturbances. Accordingly, economists have jointly applied cointegration analysis and error correction models to determine the features of money demand both in the short and in the long run.

\footnotetext{
${ }^{3}$ These dummies are defined as one in the specified period and zero elsewhere. They are: 1989:03_01, dummy1(89), 1996:01_03, dummy2(96), 2000:01_04, dummy3(00), 2005:04_01, dummy4(05) for M2 and 1991:03_02, dummy5(91), 2003:01_03 and dummy6(03) for M3. We also identify the break point 2006_04 on which, however, due to an insufficient number of observations we cannot run significance test.
} 
However, these analysis require a long pre-testing procedure to investigate variables' stationarity and a reasonable large sample of data. We try to circumvent these problems by analysing the structural consistency of demand for money in Italy over a long period of time (1977Q1-2007Q3) by applying the autoregressive distributed lag (ARDL) approach to cointegration as proposed by Pesaran et al., 2001. This methodology shows good small sample properties in comparison to standard cointegration analysis and it circumvents the shortcomings of pre-testing for stationarity that comes with other approach such as the Full Information Maximum Likelihood (FIML). Indeed, the main advantage of the ARDL approach is that it can be applied regardless of whether the regressors are $I(0)$ or $I(1)$. The approach consists first in specifying and estimating a general distributed lag model. This allows to pinpoint potential structural breaks and to establish the suitable significant lags in the variables. And, subsequently to specify an error correction model which allows to disentangle long-run dynamics from short run disturbances.

Indeed, the model in eq. (1) is more appropriately regarded as representing the equilibrium relationship in the long run, but this is unlikely to hold exactly in each single period. Hence we need a dynamic specification which is able to capture short-run adjustment processes without losing important information about the long-run equilibrium behaviour of the variables. Thus, by following Pesaran et al (2001), we specify an ARDL with an unrestricted intercept and a restricted trends ${ }^{4}$ in which the coexistence of level and difference variables can supply the ground for tests on short run and long run effects. In the specific, the empirical relationship of the model has the following dynamic representation:

$$
\begin{gathered}
\Delta \tilde{M}_{t}=\alpha_{0}+\alpha_{1} T+\sum_{i=1}^{p} \beta_{1, i} \Delta Z_{t-i}+\sum_{i=1}^{p} \beta_{2, i} \Delta \tilde{M}_{t-i}+\sum_{i=1}^{p} \gamma_{1, i} Z_{t-i}+ \\
+\sum_{i=1}^{p} \gamma_{2, i} \tilde{M}_{t-i}+\sum_{k=1}^{6} \gamma_{3, k} D_{k}+\varepsilon_{t}
\end{gathered}
$$

where $\alpha_{0}$ is the drift component, $T$ is the deterministic trend, $\Delta \tilde{M}_{t}$ is the change in real money balances ( $M 2$ and $M 3$ alternatively), $Z_{t}$ is a vector of fundamental variables (real income, interest rate, inflation and effective exchange rate) and $D_{k}$ are the dummies. The long-run multipliers are given by the vectors of coefficient $\boldsymbol{\gamma}$ 's, while the $\boldsymbol{\beta}$ 's is the vector of short-run dynamic coefficients, $p$ represents the order of the underlying ARDL-model and $\varepsilon_{t}$ are white noise errors.

Clearly, prior to test the model one needs to specify the lags. We determine the proper lag length $p$ in eq (2), with and without a deterministic linear trend, by applying the Akaike's and Schwarz's Bayesian Information Criteria (AIC and SBC, respectively, hereafter). The results are shown in tables $2 \mathrm{a}$ and $2 \mathrm{~b}$. According to Pesaran and Smith (1999) the SBC is preferable to AIC as it selects the smallest possible lag length. Hence, for the sake of parsimony, we use the SBC as the lag selection criterion and set $p=2$ for $\mathrm{M} 2$ and $p=3$ for M3.

\section{[Tables $2 a$ and $2 b$ about here]}

\footnotetext{
${ }^{4}$ Pesaran et al., 2001, p. 296.
} 
We can now focus on investigating the long run and short run effects of GDP, interest rate, inflation and nominal exchange rate on money demand. In order to detect long run multipliers and to test for their significance we employ two separate statistics. The first involves an $F$-test on the joint null hypothesis that the coefficients on the level variables are all jointly equal to zero (see Pesaran and Shin, 1999 and Pesaran et al., 2001). The second is a $t$-test on the lagged level dependent variable. We recall that these statistics have a non-standard distribution and depend on whether the variables are individually $I(0)$ or $I(1)$.

The $F$-statistic is essentially a "bound test" conducted on the ARDL error-correction model $^{5}$. Instead of the conventional critical values, this test involves two asymptotic critical value bounds, depending on whether the variables are $I(0)$ or $I(1)$ or a mixture of the two. Pesaran et al (2001) provide the critical values for this bounds test from an extensive set of stochastic simulations under different assumptions regarding the appropriate inclusion of deterministic variables. If the calculated test statistic (which is a standard $F$-test for testing the null hypothesis that the coefficients on the lagged levels terms are all jointly equal to zero) lies above the upper bound, the result is conclusive and implies that a long run relationship does exist between the variables. If the test statistic lies within the bounds, no conclusion can be drawn without knowledge of the time series properties of the variables. In this case, standard methods of testing would have to be applied. If the test statistic lies below the lower bound, no long run relationship exists. We, hence, estimate the model in equation (2) and compute the $F$ test for the joint null hypothesis $\gamma_{1, i}=\gamma_{2, i}=0$, under the alternative hypotheses that there is a stable long run level relationship between the aforementioned variables.

The bounds test results are presented in Table 3.

\section{[Tables $3 a$ and $3 b$ about here]}

The estimated long run relationship is of the form presented in eq. (2). Tables $4 \mathrm{a}$ and $4 \mathrm{~b}$ present the empirical results obtained for the period 1978Q3-2007Q3 for M2 and 1981Q1-2007Q3 for M3. Both regressions fit reasonably well and pass the main diagnostic tests. The results for both $\mathrm{M} 2$ and M3 are in line with theory expectations: in the long run all the components strongly influence, with the expected sign, money demand. In fact, the null hypothesis of no long run relationship is rejected since the $F$-statistic lies above the 0.10 upper bound which is the asymptotic critical value bounds computed by Pesaran et al. (2001).

\section{[Tables $4 a$ and $4 b$ section 2 about here]}

The constant term is positive for M2 but negative for M3. However, these are both highly significant. The coefficient on the trend variable is significant for both M2 and M3 (respectively at 5 per cent and 1 per cent). Amongst all the potential dummies, we found only two of these to be highly significant for M2: dummy2(96) at 5 per cent and dummy3(00) at 1 per cent. For M3 we found, instead, dummy5(91) and dummy6(03) to be positive and significant, the first at 5 per cent and the second at 1 per cent.

\footnotetext{
${ }^{5}$ Pesaran, Shin and Smith (2001) tabulate two sets of asymptotic critical values to provide critical value bounds for all classifications of the regressors into pure $I(1)$, purely $I(0)$ or mutually cointegrated.
} 


\footnotetext{
${ }^{6}$ Since the variable $E x$ is defined according to the IMF classification as number of units of domestic currency per US dollar, an increase in Ex raises the value of the foreign assets in terms of domestic currency. If this increase is perceived as an increase in wealth, then the demand for domestic money increases yielding a positive estimate of the coefficient of Ex. However, if an increase in Ex induces an expectation of further depreciation of the domestic currency, public may hold less of domestic currency and more of foreign currency. In this case the estimated coefficient is expected to have a negative sign.
}

The point estimate of income elasticity for M2 is 1.122 which is well above the unit level, implying that money tends to increase more proportionally than real GDP. This is an interesting finding and suggests that wealth effect, as well as portfolio choices, strongly influence the demand for liquidity through income (Fase and Winder, 1999). The elasticity of money demand is well less than one (0.8706), instead, if we consider broad money, M3. The high degree of elasticity of money demand to income in Italy suggests an oversensitive money market and a more difficult aggregate variable to control by monetary authorities. This is even more true if we consider the effect of interest rate on monetary aggregates. In fact, the point estimate of the interest rate elasticity on M2 is -0.1922 and it is even less, -0.00243 , for M3. These are significantly different from zero but very small values. Clearly, the low level of interest elasticity of money demand suggests that monetary authorities may face more difficulties in controlling money stock. Interestingly, the data show that it is much larger the point estimate of the exchange rate elasticity ${ }^{6}$ for $\mathrm{M} 2$ and M3, 0.5859 and 0.11147, respectively. The result implies that the demand for money in Italy is much more sensitive to oscillations in domestic currency rather than to movements in the interest rate. Hence, once again the results suggest a strong influence of wealth effect on money demand. In fact, we recall that the rationale for introducing the exchange rate amongst money demand's explanatory variables is indeed that devaluation of national currency is perceived as an increase in wealth and leads, by this way, to increments in the demand for money. The sign of the coefficient on inflation is also what theory predicts. In both cases of M2 and M3 the estimates of the semi-elasticity of money demand with respect to inflation are negative and significant. These, however are very small coefficients in comparison with what it has been found in the literature. Indeed, Dreger and Wolters (2006) find the inflation semi-elasticity to be about 4.52, which is a very large value in comparison to our estimates of the inflation semi-elasticity of M2 and M3, -0.0039 and -0.0029 , respectively.

Estimates of $\gamma^{\prime}$ s are used to form a lagged error-correction term, ecm ec1. $_{t}$ After replacing the linear combination of the lagged level of variables in the ARDL model (Equation 2) by $e \mathrm{~cm}_{t-1}$, the model is re-estimated by imposing the same lag structure selected by the AIC criterion. A negative and significant coefficient on $e^{c} m_{t-1}$ will be a signal of cointegration.

By including difference variables, the model takes into account the possibility that movements in the variables in any period can be related to the previous period's gap from long run equilibrium. Whenever $e \mathrm{~cm}_{t-1}$ is different from zero, money demand turns far apart from its long term equilibrium value and some sort of adjustment must occur to restore the equilibrium in the subsequent period.

\section{[Tables $4 a$ and $4 b$ section 1 about here]}


The coefficient on the error correction term, ecm, represents the speed of adjustment towards the equilibrium following a disturbance. This is -0.263 for M2 and -0.196 for M3 implying that a deviation from the long run equilibrium following a short run shock is corrected by about 26 per cent after one quarter if we consider M2 and by 19 per cent after one quarter if we consider M3.

It could be useful, at this stage, to compare some of our results with those obtained in other studies. Knell and Stix (2003, 2004) calculate different income elasticity and report that the mean and the median of all these estimates lies around unity but with a large dispersion. In addition, they show that for countries of the Euro-zone income elasticity is between 1.28 and 1.42 . Our point estimate of income elasticity is in line with their results for M2 but rather below if we consider the M3 estimations.

Moreover, it appears that our point estimate of long-run interest rate elasticity is significantly smaller than that reported by Fase (1993) which is about -0.25 and by Knell and Stix (2003) which is about -.34.

We also perform a parameter stability test for the appropriately selected ARDL representation by employing the procedure developed by Hansen and Johansen (1993). We do not use for the error correction model the Chow stability test since this requires $a$ priori knowledge of structural breaks in the estimation period and because its shortcomings are well documented.

Yet Hansen and Johansen (1993) stability tests cannot be applied to our model straightforwardly. In fact, these are usually employed to check for long-run parameter constancy in models that do not incorporate short-run dynamics and, hence, require $I(1)$ variables. These difficulties, however, can be overcome by employing the Brown et al. (1975) procedure (Pesaran and Pesaran, 1997). The Brown et al. stability testing technique, also known as cumulative sum (CUSUM) and cumulative sum of squares (CUSUMSQ) tests, are based on the recursive regression residuals. The CUSUM and CUSUMSQ statistics are updated recursively and plotted against the break points of the model. One can assume that the coefficients of a given regression are stable only when the plot of these statistics fall inside the critical bounds of 5 per cent significance. These tests are usually implemented by means of graphical representation.

\section{[Figures $4 a$ and $4 b$ about here]}

\section{[Figures $5 a$ and $5 b$ about here]}

The plots of CUSUM and CUSUMSQ statistics in figures $4 a-5 a$ and $4 b-5 b$ fall within the critical bounds implying that the coefficient estimates are robust and exhibit remarkable stability in M2 and M3 money demand.

\subsection{A further stability test of Money demand: The Kalman filter}

In this final section we estimate a "backward-looking" process for money demand in Italy with parameters varying with fundamental component of the M2 and M3 during the last three decades. We do this by implementing the Kalman filter methodology. This algorithm, which provides the recursive estimation of unobserved, time varying 
parameters or variables in the system contingent on all available information, will allow us to further investigate the long run stability of money demand coefficients.

One of the reasons to implement at this stage the Kalman filter is that "[...] when the disturbances and the initial state vector are normally distributed, it enables the likelihood function to be calculated via what is known as the prediction error decomposition. This opens the way for estimation of any unknown parameters in the model" ${ }^{7}$. Therefore, this time varying methodology is able to recover unobservable factors that could affect money demand. In addition, for each variable in the model it is possible to detect how the respective coefficients have changed over time.

Assuming that the monetary aggregate, $\Delta \tilde{M}_{i t}$, is driven by an $\operatorname{AR}(n)$ process, we apply the following time varying parameters model:

$$
\Delta \tilde{M}_{i t}=\beta_{0, t}+\beta_{1, t} Y_{t-n}+\beta_{2, t} R_{t-n}+\beta_{3, t} E x_{t-n}+\beta_{4, t} \pi_{t-n}+\mu_{i t}
$$

where $i$ is the monetary aggregate (M2 or M3), $\mu_{i t}$ is an independent white noise, the vector of coefficients $\boldsymbol{\beta}$ is assumed to be random walks. This can be written in state space form where the observation equation is given by the expression in (3) above and the state equations are given by:

$$
\left[\begin{array}{l}
\beta_{0, t} \\
\beta_{1, t} \\
\beta_{2, t} \\
\beta_{3, t} \\
\beta_{4, t}
\end{array}\right]=\left[\begin{array}{lllll}
1 & 0 & 0 & 0 & 0 \\
0 & 1 & 0 & 0 & 0 \\
0 & 0 & 1 & 0 & 0 \\
0 & 0 & 0 & 1 & 0 \\
0 & 0 & 0 & 0 & 1
\end{array}\right]\left[\begin{array}{c}
\beta_{0, t-1}, \ldots \beta_{0, t-n} \\
\beta_{1, t-1}, \ldots \beta_{1, t-n} \\
\beta_{2, t-1}, \ldots \beta_{2, t-n} \\
\beta_{3, t-1}, \ldots \beta_{3, t-n} \\
\beta_{4, t-1}, \ldots \beta_{4, t-n}
\end{array}\right]+\left[\begin{array}{c}
\mu_{t} \\
\mu_{1 t} \\
\mu_{2 t} \\
\mu_{3 t} \\
\mu_{4 t}
\end{array}\right]
$$

The latter is the measurement equation in which $\beta_{i t}$ and $\mu_{i t}$ are $[n \times 1]$ vectors ${ }^{8}$. The relevant results and estimates are reported in table 5 and in figures $6 \mathrm{a}$ and $6 \mathrm{~b}$.

All the coefficients have the correct signs and are highly significant except $\beta_{2}$ for M2. Overall, the patterns of the coefficients $\beta_{i t}$ (see figures $6 \mathrm{a}$ and $6 \mathrm{~b}$ ) seem to add insightful elements to the analysis of the dynamics of the monetary aggregates over the period.

\section{[Table 5 about here]}

\section{[Figures 6a and 6b about here]}

Indeed, it is interesting to observe that a significant change in the pattern of the coefficients occurs few years before the introduction of the Euro in 1999. This is

\footnotetext{
${ }^{7}$ Harvey (1989, p. 10).

${ }^{8}$ For a more complete explanation of the Kalman filter approach, the state space form and the measurement and transition equations, see Harvey (1989).
} 
particularly true for the coefficient on income $\left(\beta_{1}\right)$ and on the interest rate $\left(\beta_{2}\right)$ on both M2 and M3. The coefficient on income, which has been steadily decreasing over time, becomes stable around 1995-1996. Since then, the $\beta_{1}$ coefficient remains stable at around 1.1 for M2 and at .46 for M3.

A change in the pattern around the same period, 1995-1996, is also shown by the coefficient on the interest rate. This suggests that markets and money demand started to adjust in anticipation to the introduction of the Euro. The adjustment took place well before the euro was officially introduced. Not surprisingly the coefficient on the exchange rate, instead, does not show these signs of anticipated adjustments. In both cases of M2 and M3, the coefficient on the exchange rate seems to react to the introduction of the euro with a change in the pattern precisely the moment the new currency is introduced. To the other extreme, the coefficients on the inflation show an erratic dynamics over the whole period. To a more careful interpretation this pattern should not be surprising since the $\beta_{4}$ coefficient captures the effect on money demand of actual inflation and not of expected inflation which, instead, is incorporated in the movement of the interest rate.

The analysis shows that the introduction of the Euro has implied a more stable money demand and more stable coefficients for the most relevant variables for policy: that is income and interest rate.

\section{Policy Implications and Conclusions}

The introduction of a new currency is without any doubt a major change, almost a revolution, in a monetary system. Though predominant theory suggests that the adoption of a new currency should not affect real resources allocation (the so called assumption of neutrality and superneutrality of money), empirical evidence and reality might point exactly in the opposite direction. This could occur because of institutional frictions or exogenous impediments to long term realignments between nominal and real prices, or because the efficacy itself of monetary policy could be affected. In this paper, we have focused on a specific country, Italy, with a "rich" set of major events in its monetary history with the objective to uncover the effects of the introduction of the Euro on the stability of money demand and on its components. Our primary goal is indeed to verify whether monetary policy in Italy has been affected by the introduction of the Euro.

By employing bounds testing cointegration procedure proposed by Pesaran et al. (2001) we have computed short and long-run elasticities to test for the stability of the coefficients of money demand in Italy over a long period of time.

The results are quite clear and point to a significant stability of those coefficients in the short and long term. Indeed, the channels of interactions between interest rates, income and exchange rates with money remain stable trough time. And these results are in line with what previous studies have shown. This stability is quite significant and it applies to both $M 2$ and $M 3$. Yet the analysis shows that the speed of adjustment towards the equilibrium following a short run disturbance is slightly higher in the case of $M 2$. Since the Bank of Italy was explicitly targeting $M 2$ while ECB targets $M 3$, the results show the reason why the monetary policy has not lost of significance with the introduction of the new currency in Italy. 
We have also employed Kalman filtering to further investigate long term dynamics in the coefficients of money demand. The results are very insightful. The introduction of the Euro has entailed a significant increase in the stability of money demand, in particular for $M 3$. And, the effects have occurred well before the introduction of the new currency. Income, interest rates, exchange rates are all more stable since 1996 when the Lira was strongly linked to the Euro in preparation to the EMU.

Needles to say that this is a positive "side-effect" for the economy since more stable coefficients in money demand implies more efficient monetary policy. And it is interesting to notice that the greater stability of coefficients for $M 3$ plays in favour of the European policy maker.

Yet what is true for Italy might not be true for other economies. In this sense, it would be interesting to perform analogous investigations for another set of countries and to compare the results. We leave this to future research.

\section{References}

Angelini, P., D. Hendry and R. Rinaldi (1994), "An Econometric Analysis of Money Demand in Italy" Temi di discussione del Servizio Studi, Banca d'Italia, 219.

Bae, Y., V. Kakkar and M. Ogaki (2006), "Money Demand in Japan and Nonlinear Cointegration", Journal of Money, Credit, and Banking, Vol. 38, No. 6, 1659-1667.

Bagliano, F. (1996), "Money Demand in a Multivariate Framework: A System Analysis of Italian Money Demand in the '80s and Early '90s", Economic Notes, 25, 425-464.

Bahmani-Oskooee M, Chomsisengphet S. (2002) "Stability of M2 Money Demand Function in Industrial Countries", Applied Economics, vol. 34(16); 2075-83.

Bahmani-Oskooee, M. and Shabsigh, G. (1996) "The demand for money in Japan: Evidence from cointegration analysis", Japan and the World Economy, Volume 8, Issue 1, March, 1-10.

Bahmani-Oskooee, M., and M. Pourheydarian, "Exchange Rate Sensitivity of the Demand for Money and Effectiveness of Fiscal and Monetary Policies," Applied Economics, 22. 917-25.

Bahmani-Oskooee, M., Niroomand, F. and Martin, M. (1998) Exchange rate sensitivity of the demand for money in Spain, Applied Economics, 30, 607 \pm 12 .

Baumol W. (1952) "The Transaction Demand for Cash - An Inventory Theoretic Approach", Quarterly Journal of Economics, 66 (Nov.), 545-56.

Bjørnland, H. C. (2005) "A stable demand for money despite financial crisis: the case of Venezuela", Applied Economics, 37, 375-385.

Brand, C. and N. Cassola (2004) "A Money demand system for the Euro Area M3", Applied Economics, $36,817-838$.

Brown RL, Durbin J, Evans J.M. (1975) "Techniques for Testing the Constancy of Regression Relations over time", Journal of the Royal Statistical Society, series B, 37; 149-63.

Dreger, C. and J. Wolters (2006). "Investigating M3 money demand in the Euro Area : New evidence based on standard models", Discussion Papers of DIW Berlin 561, DIW Berlin, German Institute for Economic Research.

Fanelli L. and P. Paruolo (1999), New evidence on the transmission mechanism of monetary policy in Italy before Stage III of EMU.mimeo, University of Bologna

Fase, M. (1993). The stability of the demand for money in the G7 and EC countries: A survey. Research Memorandum WO\&E Nr. 9321.

Fase, M.; Winder, C. B, (1998),Wealth and the Demand for Money in the European Union,^^ Empirical. Economics, 23, 3, pp. 507-524.

Gennari, E. (1999). "Estimating Money Demand in Italy 1970-1994." EUI WP/99/7.

Granger, CWJ (1986), "Developments in the study of cointegrated economic variables", Oxford Bulletin of Economics and Statistics, 48; 213-228.

Hansen H, and Johansen S. (1993), "Recursive estimation in cointegrated Var models", Working Paper, Institute of Mathematical Statistics, University of Copenhagen.

Harvey A. (1989), Forecasting structural time series models and Kalman filter. Cambridge University Press. 
Johansen, S. (1995), Likelihood-Based Inference in Cointegrated Vector Autoregressive Models. Oxford University Press, Oxford.

Juselius, K. (1998), "Changing monetary transmission mechanisms with- in the EU", Empirical Economics, 23, 455-481.

Keynes, J. M. (1936) The General Theory of Employment, Interest and Money, First Published Macmillan Cambridge University Press, for Royal Economic Society in 1936.

Knell, M. and H. Stix (2003). How robust are money demand estimations? A meta analytic approach. Working Papers 81, Oesterreichische Nationalbank (Austrian Central Bank).

Knell, M. and H. Stix (2004). Three decades of money demand studies. Some differences and remarkable similarities. Working Papers 88, Oesterreichische Nationalbank (Austrian Central Bank).

McNown, R.M.S., and Wallace (1992), "Cointegration Tests of a Long-Run Relationship between Money Demand and the Effective Exchange Rate," Journal of International Money and Finance, 11, 107114.

Muscatelli, V. A. and Papi, L. (1990) Cointegration, financial innovation and modelling the demand for money in Italy, The Manchester School, 58, 242 \pm 59 .

Muscatelli, V. and F. Spinelli. (1996), "Modelling Monetary Trends in Italy using Historical Data: The Demand for Broad Money 1861-1990”, Economic Inquiry, 34, 579-596.

Pesaran MH, Shin Y, Smith RJ. (2001), "Bounds Testing Approaches to the Analysis of Levels Relationships", Journal of Applied Econometrics, Special Issue in honor of JD Sargan on the theme "Studies in Empirical Macroeconomics", (eds) D.F. Hedry and M.H. Pesaran; 16, 289-326.

Pesaran MH, Pesaran B, (1997) MFIT4.0, Interactive Econometric Analysis, Camfit Data Limited UK

Pesaran MH, Shin Y. An Autoregressive Distributed Lag Modeling Approach to Cointegration Analysis. In (ed) S. Strom. Econometrics and Economic Theory in the 20th Century. The Ragnar Frisch Centennial Symposium 1999, Chapter 11, Cambridge University Press.

Rinaldi, R. and R. Tedeschi. (1996), Money Demand in Italy: A System Approach. Temi di discussione del Servizio Studi, Banca d'Italia , 267

Sarno, L. (1999), “Adjustment Costs and Nonlinear Dynamics in the Demand for Money: Italy, 1861 1991", International Journal of Finance and Economics, 4, 155-177. 


\section{Appendix}

\section{Figure 1}
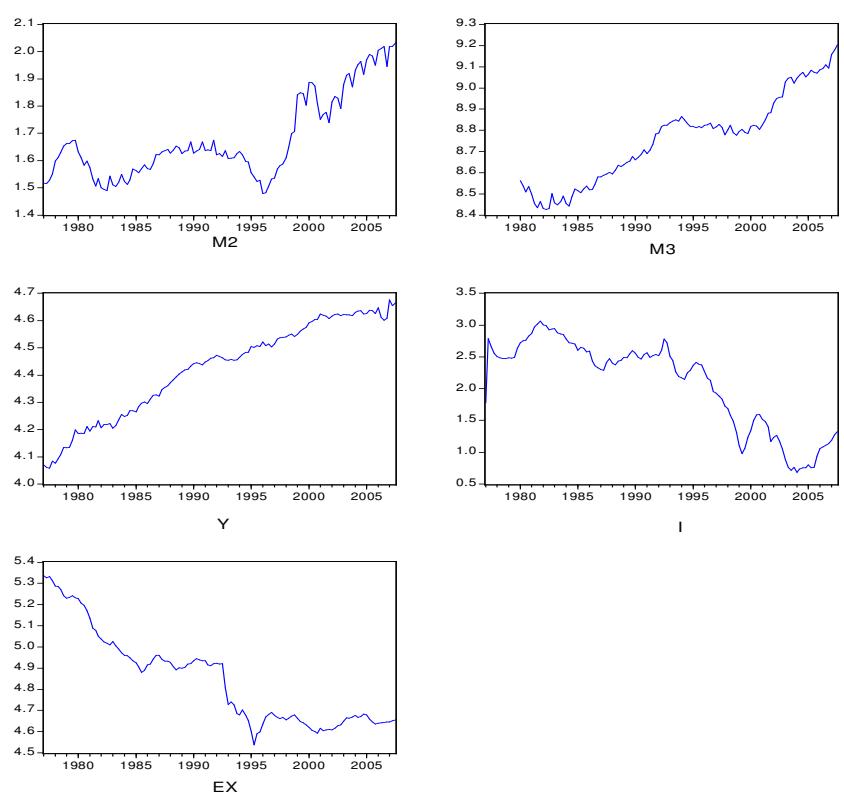

Figure 2 Recursive residuals M2

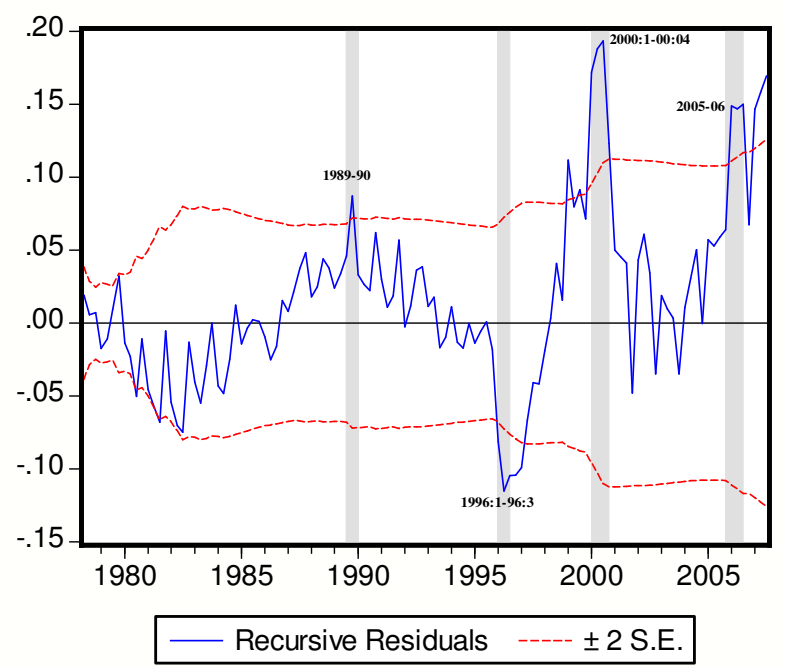

Editorial Office, Dept of Economics, Warwick University, Coventry CV4 7AL, UK 
Figure 3 Recursive residuals M3

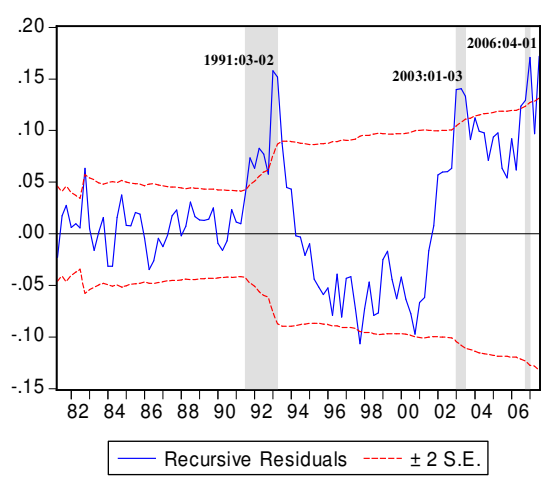

Figure 4 a M2

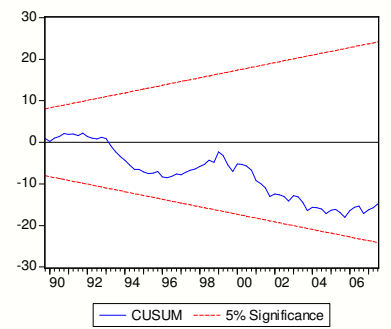

Figure 5 a $M 2$

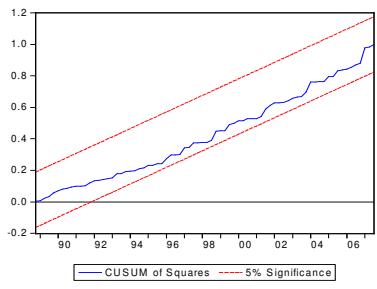

Figure $4 \mathrm{~b} M 3$

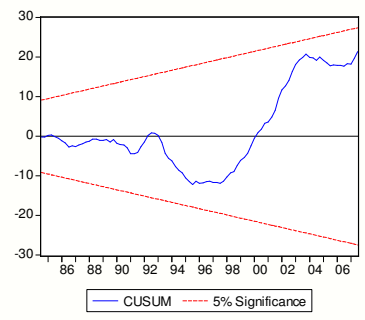

Figure $5 b \mathrm{M3}$

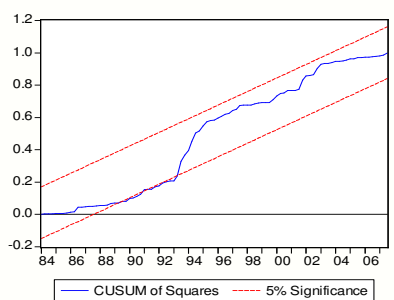

Figure 6a Time varying coefficients for M2
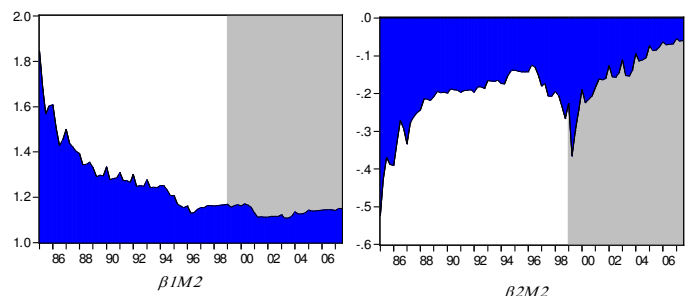

$\beta 2 M 2$

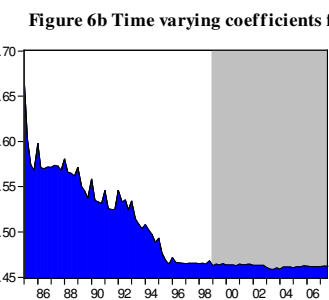

$\beta I M 3$

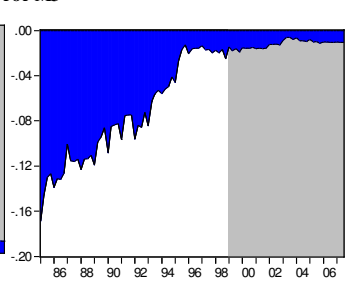

$\beta 2 M 3$

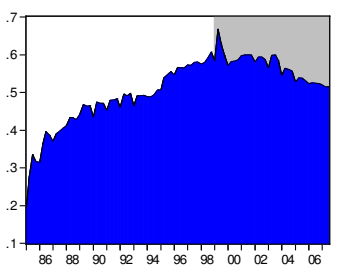

$\beta 3 M 2$

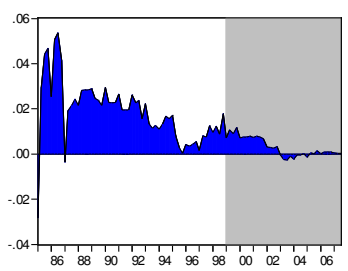

$\beta 3 M 3$

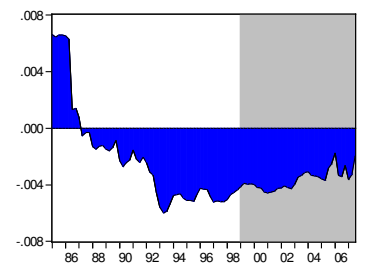

$\beta 4 M 2$

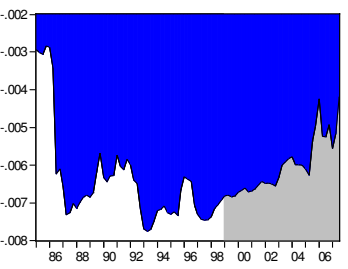

$\beta 4 M 3$ 
Table 1 Stability test results

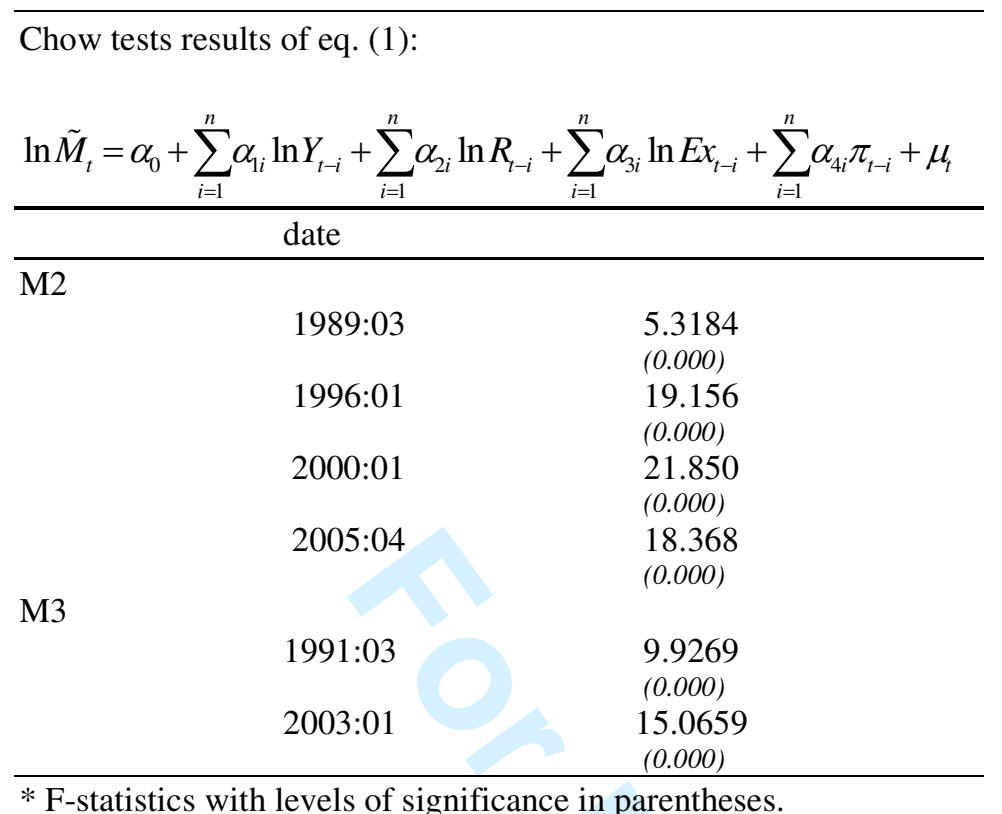

Table 2a Lag-length Selection criteria

\begin{tabular}{ccccc}
\hline M2 & \multicolumn{2}{l}{ With deterministic trend } & \multicolumn{2}{l}{ Without deterministic trend } \\
\hline Lags & AIC & SBC & AIC & SBC \\
\hline $\mathrm{K}=1$ & -2.9516 & -2.8367 & -2.7796 & -2.6874 \\
$\mathrm{~K}=2$ & -3.1338 & $-3.0462^{\star}$ & -3.0926 & $-2.9308^{\star}$ \\
$\mathrm{K}=3$ & $-3.3317^{\star}$ & -3.0124 & $-3.3348^{\star}$ & -2.9127 \\
$\mathrm{~K}=4$ & -3.3293 & -2.9850 & -3.2352 & -2.9016 \\
$\mathrm{~K}=5$ & -3.2841 & -2.9490 & -3.2044 & -2.8987 \\
$\mathrm{~K}=6$ & -3.2677 & -2.8956 & -3.2248 & -2.8762 \\
\hline
\end{tabular}

Notes: the lag order is selected on the basis of AIC and SBC and indicates the lag length choice according to the two criteria respectively. 
Table $2 b$ Lag-length Selection criteria

\begin{tabular}{ccccc}
\hline M3 & \multicolumn{2}{c}{ With deterministic trend } & \multicolumn{2}{c}{ Without deterministic trend } \\
\hline Lags & AIC & SBC & AIC & SBC \\
\hline $\mathrm{K}=1$ & -3.5227 & -3.2240 & -3.5412 & -3.2680 \\
$\mathrm{~K}=2$ & -3.7073 & -3.4075 & -3.7223 & -3.4485 \\
$\mathrm{~K}=3$ & $-5.1253^{\star}$ & $-4.8238^{\bullet}$ & $-5.1368^{\bullet}$ & $-4.8604^{\bullet}$ \\
$\mathrm{K}=4$ & -3.7693 & -3.4660 & -3.7854 & -3.5074 \\
$\mathrm{~K}=5$ & -3.5703 & -3.2652 & -3.5888 & -3.3091 \\
$\mathrm{~K}=6$ & -3.6885 & -3.3922 & -3.7054 & -3.4338 \\
\hline
\end{tabular}

Notes: the lag order is selected on the basis of AIC and SBC and indicates the lag length choice according to the two criteria respectively.

Table 3 a Bounds tests

\begin{tabular}{|c|c|c|c|}
\hline \multirow[t]{2}{*}{ M2 } & \multicolumn{3}{|c|}{ Unrestricted intercept and no trend $\quad$ Unrestricted intercept and restricted trend } \\
\hline & F-stat & $\begin{array}{c}\begin{array}{c}\text { Upper critical } \\
\text { value }\end{array} \\
\text { F-stat }\end{array}$ & $\begin{array}{l}\text { Upper critical } \\
\text { value }\end{array}$ \\
\hline $\mathrm{K}=1$ & $\mathrm{~F}(6,105)=6.071709 * *$ & $\mathrm{~F}(5,104)=7.758018 * *$ & 7.63 \\
\hline $\mathrm{K}=2$ & $\mathrm{~F}(9,105)=4.246327 *$ & $\mathrm{~F}(8,104)=7.177243 * *$ & 6.15 \\
\hline \multicolumn{4}{|c|}{$\begin{array}{l}\text { Notes: the } F \text {-statistic is used to test for the joint significance of the coefficients of the lagged levels in the ARDL- } \\
\text { ECM. Asymptotic critical values are obtained from Table CI(iii) Case III: unrestricted intercept and no trend for } \mathrm{k}=1 \\
\text { and K=2 and from Table CI(iv) Case IV: unrestricted intercept and restricted trend for } \mathrm{k}=1 \text { and } \mathrm{K}=2 \text { (Pesaran et al., } \\
\text { 2001, pp. 300-301). }\end{array}$} \\
\hline
\end{tabular}

Table 3 b Bounds tests

\begin{tabular}{|c|c|c|c|c|}
\hline \multirow[t]{2}{*}{ M3 } & \multicolumn{2}{|c|}{ Unrestricted intercept and no trend } & \multicolumn{2}{|c|}{ Unrestricted intercept and restricted trend } \\
\hline & F-stat & $\begin{array}{l}\text { Upper critical } \\
\text { value }\end{array}$ & F-stat & $\begin{array}{c}\text { Upper critical } \\
\text { value }\end{array}$ \\
\hline $\mathrm{K}=1$ & $\mathrm{~F}(7,87)=15.4762 * *$ & 5.73 & $\mathrm{~F}(7,86)=12.33394 * *$ & 7.63 \\
\hline $\mathrm{K}=2$ & $\mathrm{~F}(9,87)=12.6051 * *$ & 4.85 & $\mathrm{~F}(9,86)=16.1677 * *$ & 6.15 \\
\hline \multicolumn{5}{|c|}{$\begin{array}{l}\text { Notes: the } F \text {-statistic is used to test for the joint significance of the coefficients of the lagged levels in the ARDL- } \\
\text { ECM. Asymptotic critical values are obtained from Table CI(iii) Case III: unrestricted intercept and no trend for k=1 } \\
\text { and K=2 and from Table CI(iv) Case IV: unrestricted intercept and restricted trend for } \mathrm{k}=1 \text { and } \mathrm{K}=2 \text { (Pesaran et al., } \\
\text { 2001, pp. 300-301). }\end{array}$} \\
\hline
\end{tabular}


Table 4a ARDL eq. (2 )- M2 (monetary aggregate)

\begin{tabular}{|c|c|c|c|c|c|c|}
\hline \multicolumn{7}{|c|}{ Section 1, Short-run coefficient estimates } \\
\hline Lag order & & 1 & \multirow{6}{*}{\multicolumn{2}{|c|}{$\begin{array}{c}\mathbf{2} \\
-0.163348 * \\
(-2.534315)\end{array}$}} & \multirow{2}{*}{\multicolumn{2}{|c|}{3}} \\
\hline$\Delta \mathrm{M} 2$ & & & & & & \\
\hline$\Delta y$ & & $\begin{array}{l}-0.205291 \\
(-1.071735)\end{array}$ & & & & \\
\hline$\Delta R$ & & $\begin{array}{r}-0.178928 \\
(-1.780284)\end{array}$ & & & & \\
\hline$\Delta E x$ & & $\begin{array}{r}0.189776 \\
(2.789043)\end{array}$ & & & & \\
\hline$\Delta \pi$ & & $\begin{array}{r}0.003815^{\circ} \\
(1.969173) \\
\end{array}$ & & & & \\
\hline \multicolumn{7}{|c|}{ Section 2, Long-run coefficient estimates } \\
\hline$C$ & $\mathrm{Y}$ & $\mathrm{R}$ & Ex & $\pi$ & $\mathrm{ecm}$ & $T$ \\
\hline $\begin{array}{l}1.679842 * * \\
(3.156399)\end{array}$ & $\begin{array}{l}1.121902^{*} \\
(2.661021)\end{array}$ & $\begin{array}{l}-0.192259 * * \\
(-13.58660)\end{array}$ & $\begin{array}{l}0.585904^{* *} \\
(7.856711)\end{array}$ & $\begin{array}{c}-0.003929 * * \\
(-4.996217)\end{array}$ & $\begin{array}{c}-0.262995 * * \\
(-4.067704)\end{array}$ & $\begin{array}{l}0.002282 * \\
(2.44829)\end{array}$ \\
\hline Dummy2(96) & & & & & & $\begin{array}{c}-0.110086^{*} \\
(-3.59512)\end{array}$ \\
\hline Dummy3(00) & & & & & & $\begin{array}{l}0.102256^{* * *} \\
(3.666468)\end{array}$ \\
\hline
\end{tabular}

Section 3 Diagnostics

Adjusted R-squared: 0.49247; Durbin-Watson stat: 2.16438; $\chi_{S C}^{2}(3)=4.303[0.1162] ; \chi_{F F}^{2}(1)=0.374[0.9437]$; $\chi_{N}^{2}(2)=7.999[0.6212] ; \quad \chi_{H}^{2}(1)=0.275[0.5994]$.

significant at the 0.10 level; *significant at the 0.05 level; **significant at the 0.01 level ; Obs. 117 ( quarterly)

Table 4b ARDL eq. (2)-M3 (monetary aggregate)

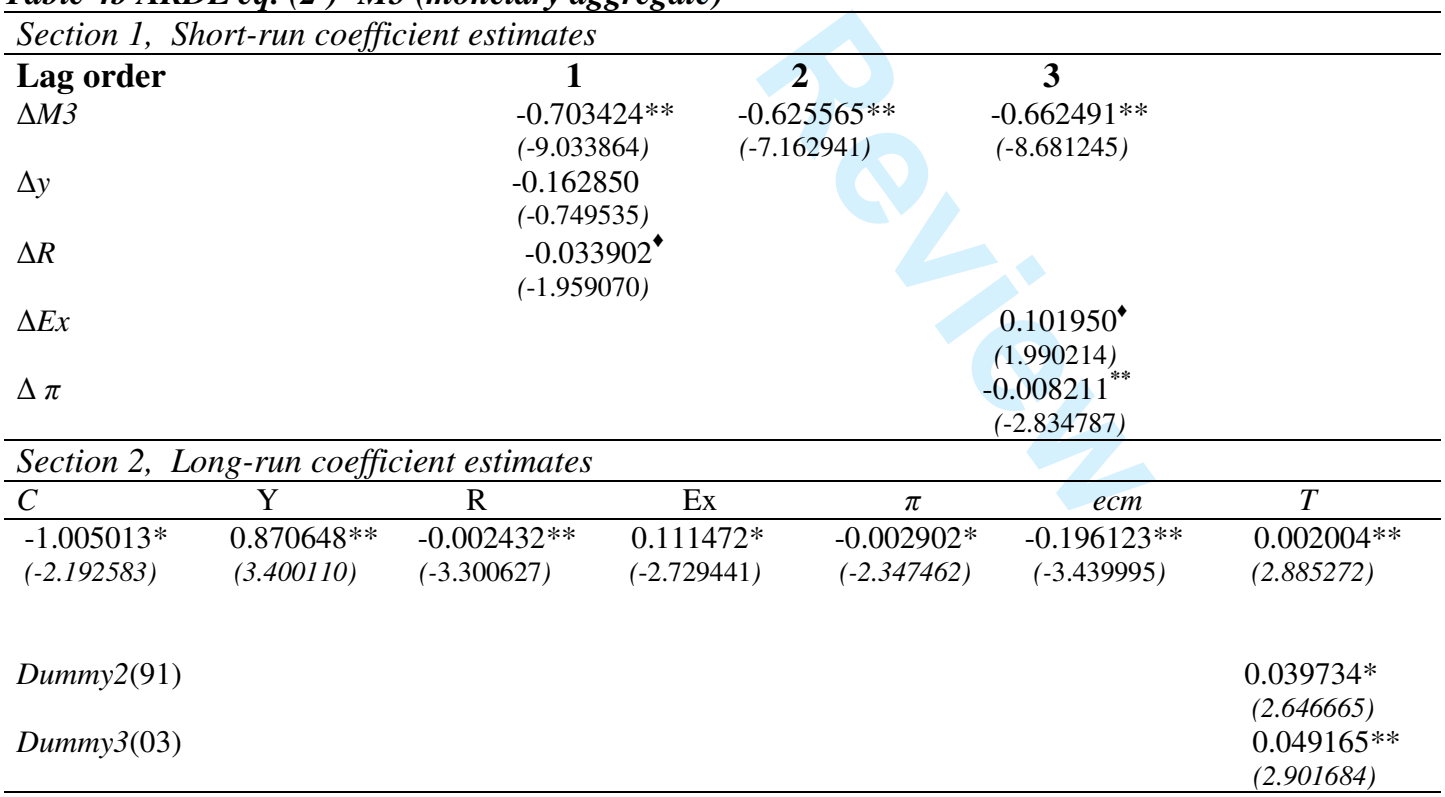

Section 3, Diagnostics

Adjusted R-squared: 0.5927; Durbin-Watson stat: 2.2254; $\chi_{S C}^{2}(3)=4.121[0.12741] ; \chi_{F F}^{2}(1)=0.667[0.4139]$; $\chi_{N}^{2}(2)=3.129[0.3169] ; \quad \chi_{H}^{2}(1)=0.405[0.5244]$.

significant at the 0.10 level; *significant at the 0.05 level; **significant at the 0.01 level ; Obs. 107 ( quarterly) 
Table 5 The Kalman estimations

\begin{tabular}{|c|c|c|c|c|c|}
\hline$(\Delta M 2)$ & $\beta_{1, t}$ & $\beta_{2, t}$ & $\beta_{3, t}$ & $\beta_{4, t}$ & $\sigma_{\mu, t}^{2}$ \\
\hline $\begin{array}{l}\text { AIC }=-3.27 \\
\text { Schwarz=-3.15 } \\
\text { Obs. 123(Q) }\end{array}$ & $\begin{array}{c}1.2564 * * \\
(5.7511) \\
{[0.000]} \\
\end{array}$ & $\begin{array}{l}-0.0837 \\
(-1.7588) \\
{[0.0635]}\end{array}$ & $\begin{array}{c}0.03982 * * \\
(15.359) \\
{[0.000]} \\
\end{array}$ & $\begin{array}{c}-0.002941 * * \\
(3.1198) \\
{[0.000]} \\
\end{array}$ & $\begin{array}{c}-3.1162 * * \\
(-76.265) \\
{[0.000]} \\
\end{array}$ \\
\hline (4M3) & $\beta_{1, t}$ & $\beta_{2, t}$ & $\beta_{3, t}$ & $\beta_{4, t}$ & $\sigma_{\mu, t}^{2}$ \\
\hline $\begin{array}{l}\text { AIC }=-2.95 \\
\text { Schwarz=-2.83 } \\
\text { Obs. } 110(\mathrm{Q})\end{array}$ & $\begin{array}{c}0.5822 * * \\
(2.997) \\
{[0.000]} \\
\end{array}$ & $\begin{array}{c}-0.0187 * * \\
(-3.158) \\
{[0.0016]} \\
\end{array}$ & $\begin{array}{c}0.3547 * * \\
(21.477) \\
{[0.000]} \\
\end{array}$ & $\begin{array}{c}-0.003557 * * \\
(-4.289) \\
{[0.000]} \\
\end{array}$ & $\begin{array}{c}-2.1383 * * \\
(-44.5591) \\
{[0.000]} \\
\end{array}$ \\
\hline
\end{tabular}

*significant at the 0.05 level; **significant at the 0.01 level ; z-statistics in brackets; $p$-value in squared brackets. 